\title{
Filozoficzne koncepcje nieostrości
}

\section{Joanna Odrowąż-Sypniewska}

Uniwersytet Warszawski

\section{Co to jest nieostrość?}

Dla filozofów języka nieostrość jest tą cechą wyrażeń, która prowadzi do paradoksu łysego/ kopca ${ }^{1}$ : innymi słowy wyrażenia nieostre to te, dla których da się taki paradoks sformułować. Terminy nieostre (takie jak: 'łysy', 'krótki', 'chudy', 'bogaty', 'inteligentny' itd.) to wyrażenia, których cechą charakterystyczną jest ich (pozorna przynajmniej) tolerancyjność. Weźmy nieostry predykat $P^{2}$. Jeśli $P$ stosuje się do $x$-a, to wydaje się, że maleńka zmiana $x$-a pod względem relewantnym ze względu na $P$ nie powinna wpłynąć na możliwość zastosowania do niego predykatu $P$. Na przykład, jeśli do $x-$ a stosuje się predykat 'chudy', to przytycie przez $x$ o 1 gram nie wpłynie na zastosowanie do niego tego predykatu. (Natomiast wyrażenia nieostre nie są tolerancyjne: jeśli ktoś, do kogo stosuje się predykat 'waży dokładnie $50 \mathrm{~kg}$ ', przytyje o 1 gram, to ów predykat przestanie się do niego stosować). Tolerancyjność jest bardzo istotną cechą wyrażeń nieostrych, ale to właśnie ta cecha prowadzi do powstawania paradoksów. Paradoks łysego formułuje się zazwyczaj na dwa sposoby:

1. Człowiek, który ma 0 włosów na głowie, jest łysy.

Jeżeli człowiek, który ma 0 włosów na głowie, jest łysy, to i człowiek, który ma 1 włos na głowie, jest łysy.

Jeżeli człowiek, który ma 149999 włosów na głowie, jest łysy, to i człowiek, który ma 150000 włosów na głowie, jest łysy.

Człowiek, który ma 150000 włosów na głowie, jest łysy.

\footnotetext{
${ }^{1}$ Paradoksy kopca i łysego zostały sformułowane najprawdopodobniej przez Eubulidesa z Miletu w 330 r. p.n.e.

${ }^{2}$ Predykaty są najbardziej typowymi wyrażeniami nieostrymi.
} 
2. Człowiek, który ma 0 włosów na głowie, jest łysy.

Dla każdego $k$, jeśli człowiek, który ma $k$ włosów na głowie, jest łysy ${ }^{3}$, to i człowiek, który ma $k+1$ włosów na głowie, jest łysy.

Człowiek, który ma 150000 włosów na głowie, jest łysy.

W sformułowaniu (1) mamy do czynienia z wielokrotnym zastosowaniem modus ponendo ponens. Od przesłanek 'Człowiek, który ma 0 włosów na głowie, jest łysy' i 'Jeżeli człowiek, który ma 0 włosów na głowie, jest łysy, to i człowiek, który ma 1 włos na głowie, jest łysy’ dochodzimy do wniosku pośredniego 'Człowiek, który ma 1 włos na głowie, jest łysy'. Ten wniosek staje się przesłanką kolejnego kroku rozumowania.

W sformułowaniu (2) z dwóch intuicyjnie prawdziwych przesłanek: kategorycznej i warunkowej, wyprowadzamy wniosek, który jest w sposób oczywisty fałszywy. Przesłanka warunkowa bywa nazywana 'zasadą tolerancji’, ponieważ wydaje się, iż to ona właśnie wyraża tolerancyjność wyrażeń nieostrych.

Warto podkreślić, że paradoks można również zbudować w drugą stronę:

Człowiek, który ma 150000 włosów na głowie, nie jest łysy.

Dla każdego $k$, jeśli człowiek, który ma $k$ włosów na głowie, nie jest łysy, to i człowiek, który ma $k-1$ włosów na głowie, nie jest łysy.

Człowiek, który ma 0 włosów na głowie, nie jest łysy.

Nie możemy zatem poprzestać na stwierdzeniu, że paradoks łysego pokazuje, że wszyscy są w istocie łysi. Paradoks ów prowadzi bowiem do sprzecznych wniosków: wszyscy są łysi i wszyscy są niełysi!

Inną charakterystyczną cechą wyrażeń nieostrych jest posiadanie (aktualnych lub potencjalnych) przypadków granicznych, czyli takich przypadków, o których nie można powiedzieć, czy dany termin się do nich stosuje czy nie.

\footnotetext{
${ }^{3}$ Jeśli ktoś uważa, że łysy jest tylko ten, kto ma 0 włosów na głowie, to powinien mieć świadomość, że nie używa słowa 'łysy' tak, jak jest ono potocznie używane. Ponadto analogiczny paradoks można sformułować dla słowa 'łysawy', w którym pierwsza przesłanka będzie mówiła o człowieku mającym 1 włos na głowie. Na marginesie: abstrahujemy tutaj od koloru włosów, ich gęstości, rozmieszczenia na głowie itp. Ponieważ paradoks łysego był jednym z pierwszych sformułowanych paradoksów nieostrości, nadal przy formułowaniu paradoksów nieostrości często używa się predykatu „łysy”. Trzeba jednak zauważyć, że jest to wyjątkowo zły wybór, ponieważ jest oczywiste, że to, czy ktoś jest uznawany za łysego, czy nie, nie zależy wyłącznie od liczby włosów na jego głowie).
} 
Polak, który ma $190 \mathrm{~cm}$ wzrostu, jest wysoki; Polak, który ma $165 \mathrm{~cm}$, nie jest wysoki; ale nie jest jasne, czy Polak, który ma $175 \mathrm{~cm}$ wzrostu jest wysoki, czy nie. Ten ostatni będzie zatem przypadkiem granicznym wyrażenia „wysoki”. Ponieważ nie mamy jednoznacznych intuicji dotyczących tego, czy Polak mający $175 \mathrm{~cm}$ wzrostu jest wysoki, nie wiemy, jaką wartość logiczną przypisać zdaniu 'Polak mający $175 \mathrm{~cm}$ wzrostu jest wysoki'. Przypadki graniczne tworzą zakres nieostrości.

Trzeba tutaj wyraźnie zaznaczyć, że chociaż wyrażenia nieostre są zależne od kontekstu, to nieostrości nie da się sprowadzić do zależności kontekstowej. Nawet jeśli kontekst zostanie wyznaczony bardzo precyzyjnie (np. ustalimy, że mówimy o wzroście studentów płci męskiej określonego wydziału danego uniwersytetu), to termin 'wysoki' w zastosowaniu do tej grupy pozostanie nieostry.

\section{Nieostrość a niewyraźność}

Nieostrość jest cechą e k s te n s j i wyrażeń: wyrażenie jest nieostre, jeśli są (lub mogłyby być) takie przedmioty, co do których nie da się orzec, czy należą do ekstensji tego wyrażenia. Co ważne, ta niemożność orzeczenia nie jest wynikiem niewiedzy dotyczącej przedmiotów, o których dany predykat jest orzekany. Analogiczną do nieostrości cechą znaczenia (konotacji) wyrażeń jest niewyraźność. Wyrażenie jest niewyraźne, jeśli jego znaczenie jest takie, że co do pewnej cechy nie można orzec, czy należy ona do tego znaczenia. Najczęściej podawanym przykładem wyrażenia niewyraźnego jest 'kłamstwo'. Znaczenie tego wyrażenia jest takie, że nie wiadomo, czy cecha fałszywości do niego należy (czy można skłamać mówiąc prawdę?). Sądzę, że związki między nieostrością a niewyraźnością są następujące: każde wyrażenie niewyraźne jest przynajmniej potencjalnie nieostre (bo może mieć przypadki graniczne), ale nie każde wyrażenie nieostre jest niewyraźne. Nieostre wyrażenia o złożonej konotacji (takie, jak 'kłamstwo') są niewyraźne, ale nieostre wyrażenia o prostej konotacji (takie, jak 'wysoki') nie są niewyraźne. W ich wypadku nie ma bowiem takich cech, co do których jest nieokreślone, czy należą do ich konotacji czy nie ${ }^{4}$.

\footnotetext{
${ }^{4}$ Kwestią związków między nieostrością a niewyraźnością zajmowałam się w artykule „O nieostrości i niewyraźności” (Odrowąż-Sypniewska 2005).
} 


\section{Semantyczne i epistemiczne rozwiązania paradoksu nieostrości}

Adekwatna koncepcja nieostrości powinna, po pierwsze, wskazywać, w jaki sposób należy rozwiązać paradoks nieostrości, a po drugie, określić, jak należy traktować przypadki graniczne. Jeśli mamy do czynienia z przypadkiem granicznym predykatu 'wysoki student wydziału $X$ ', to nie wiemy, czy ten predykat możemy do owego przypadku granicznego zastosować i - w szczególności - nie wiemy, jaka byłaby wartość logiczna zdania, w którym ów predykat temu przypadkowi zostałby przypisany. Właściwa koncepcja nieostrości powinna tej niewiedzy zaradzić.

Paradoks nieostrości - tak, jak każdy inny paradoks - można rozwiązać na cztery sposoby: (1) odrzucając przesłanki; (2) wskazując błąd w rozumowaniu (ze względu na zastosowane reguły wnioskowania); (3) odrzucając przyjęte reguły wnioskowania; (4) akceptując wniosek.

Odrzucenie przesłanki kategorycznej ('Człowiek, który ma 0 włosów na głowie, jest łysy'; 'Człowiek, który ma 150000 włosów na głowie, nie jest łysy'), podobnie jak zaakceptowanie wniosku ('Człowiek, który ma 150000 włosów na głowie, jest łysy'; 'Człowiek, który ma 0 włosów na głowie, nie jest łysy') ma bardzo radykalne konsekwencje, prowadzi bowiem do wniosku, że nie ma łysych ani owłosionych; wysokich ani niewysokich, chudych ani niechudych itd. Z oczywistych względów są to więc rozwiązania, które nie znajdują wielu zwolenników ${ }^{5}$. Rozwiązanie trzecie również ma daleko idące konsekwencje, ponieważ - w zależności od sformułowania - rozumowanie, które prowadzi do paradoksu, korzysta albo z modus ponens albo z indukcji matematycznej. Jako niepoprawny modus ponens został odrzucony przez niektórych zwolenników stopni prawdy. Koncepcja stopni prawdy zakłada, że zdania mogą być prawdziwe w różnym stopniu. Rozważmy następujący krok wnioskowania:

Człowiek, który ma 10 włosów na głowie, jest łysy.

Jeżeli człowiek, który ma 10 włosów na głowie, jest łysy, to i człowiek, który ma 11 włosów na głowie, jest łysy.

Człowiek, który ma 11 włosów na głowie, jest łysy.

\footnotetext{
5 Jednym z takich zwolenników jest Peter Unger (1979: 149), który twierdzi, że paradoksy nieostrości demonstrują ,nędzę naszego języka i naszych myśli i wskazują potrzebę znalezienia nowych wyrażeń".
} 
Pierwsza przesłanka jest intuicyjnie prawdziwa w wyższym stopniu niż druga, która z kolei jest prawdziwsza niż wniosek. To, czy z tego powodu odrzucimy modus ponens jako błędny sposób rozumowania, zależy od przyjętej definicji poprawności formalnej wnioskowania. Jeśli uznamy, że wnioskowanie jest poprawne, gdy zachowuje stopień prawdziwości (tj. wniosek nie może być mniej prawdziwy niż przesłanki użyte do jego wyprowadzenia), to modus ponens trzeba uznać za niepoprawny sposób rozumowania.

Większość proponowanych rozwiązań sprowadza się do odrzucenia przesłanki hipotetycznej:

Dla każdego $k$, jeśli człowiek, który ma $k$ włosów na głowie, jest łysy, to i człowiek, który ma $k+1$ włosów na głowie, jest łysy.

Zazwyczaj przyjmuje się, że to ta przesłanka jest odpowiedzialna za powstanie paradoksu. Tak, jak już wspominałam, przesłanka hipotetyczna mówi w istocie o tolerancyjności wyrażeń nieostrych. Odrzucając tę przesłankę, odrzucamy jednocześnie tolerancyjność. Nie da się jednak zaprzeczyć, że wyrażenia nieostre wydaja się tolerancyjne. Ktoś, kto neguje przesłankę hipotetyczną, musi zatem wytłumaczyć, jak to się dzieje, że wyrażenia nieostre uważamy za tolerancyjne (mimo że wcale takie nie są).

Delia Fara (2000) zauważyła trafnie, że rozwiązanie paradoksu nieostrości wymaga uporania się z trzema pytaniami: semantycznym, epistemologicznym i psychologicznym. Pytanie semantyczne brzmi: jeśli przesłanka hipotetyczna rozumowania prowadzącego do paradoksu nie jest prawdziwa, to czy prawdziwa jest jej (klasyczna) negacja? Negacją przesłanki hipotetycznej jest twierdzenie, że jest takie $k$, że człowiek, który ma $k$ włosów na głowie, jest łysy, a człowiek, który ma $k+1$ włosów na głowie, już łysy nie jest. Negacja ta sprowadza się zatem do twierdzenia o istnieniu ostrej granicy między łysymi a niełysymi. Jeśli chcemy to twierdzenie zaakceptować, to musimy wskazać, w jaki sposób jego prawdziwość daje się pogodzić z istnieniem przypadków granicznych. Jeśli zaś nie chcemy uznać, że to twierdzenie jest prawdziwe, to musimy odrzucić logikę klasyczną i zamiast niej wskazać jakąś inną (taką, w której fałszem jest zarówno $' \forall k(F(k) \rightarrow F(k+1))$ ', jak i ' $\exists k(F(k) \wedge \sim F(k+1)$ '). Odpowiedź na pytanie epistemologiczne wymaga powiedzenia, dlaczego - skoro przesłanka hipotetyczna jest fałszywa - nie jesteśmy w stanie wskazać tych przypadków, które ją falsyfikują. Pytanie psychologiczne brzmi: Skoro przesłanka hipotetyczna jest fałszywa, to dlaczego tak chętnie ją przyjmujemy? Podsumowując, autorka „Shifting sands: An interest-relative theory of vagueness", pisze: 
[...] odpowiedź na [pytania epistemologiczne i psychologiczne - J. O.-S.] zmusza nas do wyjaśnienia dlaczego predykaty nieostre wydają się nam tolerancyjne, mimo że rozumowanie [paradoksu nieostrości - J. O.-S.] pokazuje, że takie być nie mogą (Fara 2000: 54).

Rozwiązania paradoksów można podzielić na semantyczne i epistemiczne. Rozwiązania semantyczne zakładają, że wyrażenia nieostre rzeczywiście mają niedookreślone ekstensje, podczas gdy rozwiązanie epistemiczne przyjmuje, że ekstensje wyrażeń nieostrych są precyzyjnie wytyczone, tyle że my nie wiemy (i nigdy się nie dowiemy), którędy granice tych ekstensji przebiegają ${ }^{6}$.

\subsection{Nadwartościowanie}

Najpopularniejszym rozwiązaniem semantycznym jest rozwiązanie odwołujące się do nadwartościowania (superwaluacji). Zwolennicy takiego rozwiązania wychodzą od spostrzeżenia, że wyrażenia nieostre można doprecyzowywać na wiele sposobów (por. Fine 1975) ${ }^{7}$. Na przykład, można przyjąć, że wysoki student wydziału $X$, to taki, który ma (a) powyżej $195 \mathrm{~cm}$ wzrostu; (b) powyżej $190 \mathrm{~cm}$ wzrostu; (c) powyżej $185 \mathrm{~cm}$ wzrostu; ... (n) powyżej $160 \mathrm{~cm}$ wzrostu. Spośród tych możliwych sposobów doprecyzowania niektóre są dopuszczalne ze względu na znaczenie precyzowanego predykatu (np. (a)-(c)), a inne nie (np. (n)). Doprecyzowanie jest dopuszczalne, gdy nie narusza ekstensji i antyekstensji, tj. gdy przeprowadza granicę gdzieś w obrębie zakresu nieostrości. Dopuszczalne doprecyzowania są równouprawnione. W obrębie każdego z dopuszczalnych doprecyzowań predykatu ,wysoki”, każde zdanie przypisujące bycie wysokim jakiemuś człowiekowi będzie prawdziwe albo fałszywe, nawet jeśli ten człowiek jest granicznym przypadkiem bycia wysokim. Zatem w każdym dopuszczalnym doprecyzowaniu zdanie 'Polak mający $175 \mathrm{~cm}$ wzrostu jest wysoki’ będzie posiadało jedną z dwóch klasycznych wartości logicznych. W tych doprecyzowaniach, w których granica między wysokimi a niewysokimi przebiega poniżej $175 \mathrm{~cm}$, będzie prawdziwe, a w tych, w których przebiega na $175 \mathrm{~cm}$ lub powyżej - fałszywe. Odpowiednie przypisanie wartości logicznych zdaniom wewnątrz doprecyzowania nazywane jest dopuszczalnym wartościo-

\footnotetext{
${ }^{6}$ Pisałam wyżej, że nieznajomość granic ekstensji nie da się wytłumaczyć niewiedzą dotyczącą przedmiotów, o których orzekany jest dany predykat nieostry. Rozwiązanie epistemiczne również się pod tą tezą podpisuje: niewiedza dotycząca położenia granic ekstensji bierze się z niewiedzy dotyczącej sposobów użycia wyrażeń nieostrych, a nie z niewiedzy dotyczącej jakichś cech przedmiotów, o których wyrażenia nieostre są orzekane. Por. niżej.

${ }^{7}$ Każde z takich doprecyzowań można traktować jako definicję regulującą.
} 
waniem. Nadwartościowanie jest funkcją, która przypisuje nadprawdę tym zdaniom, którym prawda została przypisana przez wszystkie dopuszczalne wartościowania, a nadfałsz - tym zdaniom, którym wszystkie dopuszczalne wartościowania przypisały fałsz. Zdaniom, którym w różnych precyzacjach przypisano różne wartości logiczne, nadwartościowanie nie przypisuje żadnej wartości logicznej. Głównym założeniem nadwartościowania jest utożsamienie prawdy z nadprawdą, a fałszu - z nadfałszem. Zdania mówiące o przypadkach granicznych są więc pozbawione wartości logicznej.

Zdanie 'Jeśli Jaś, który ma $176 \mathrm{~cm}$ wzrostu, jest wysoki, to Staś, który ma $175 \mathrm{~cm}$ wzrostu, też jest wysoki', nie będzie ani nadprawdziwe, ani nadfałszywe, ponieważ może istnieć dopuszczalne doprecyzowanie, zgodnie z którym tylko ludzie, którzy mają co najmniej $176 \mathrm{~cm}$ wzrostu są wysocy. W takim doprecyzowaniu poprzednik 'Jaś, który ma $176 \mathrm{~cm}$ wzrostu, jest wysoki' jest zdaniem prawdziwym, ale następnik 'Staś, który ma $175 \mathrm{~cm}$ wzrostu, jest wysoki' jest fałszywy. Cała implikacja będzie zatem fałszywa. Jednakże w innym dopuszczalnym doprecyzowaniu granica między wysokimi a niewysokimi może przebiegać na $175 \mathrm{~cm}$. W takim doprecyzowaniu implikacja będzie prawdziwa. Ponieważ implikacja 'Jeśli Jaś, który ma $176 \mathrm{~cm}$ wzrostu, jest wysoki, to Staś, który ma $175 \mathrm{~cm}$ wzrostu, też jest wysoki' ma różne wartości logiczne $w$ różnych dopuszczalnych doprecyzowaniach, to nadwartościowanie nie przypisuje jej ani (nad-)prawdy, ani (nad-)fałszu.

Rozwiązanie paradoksu nieostrości polega na przyjęciu, że rozumowanie prowadzące do tego paradoksu jest obarczone błędem materialnym, bowiem zawiera fałszywą przesłankę. Przesłanka:

(1) Dla każdego $k$, jeśli człowiek, który ma $k$ mm wzrostu, jest wysoki, to człowiek, który ma $k-1 \mathrm{~mm}$ wzrostu, też jest wysoki,

jest fałszywa, a jej negacja:

(2) Istnieje $k$ takie, że człowiek, który ma $k \mathrm{~mm}$ wzrostu, jest wysoki, ale człowiek, który ma $k-1 \mathrm{~mm}$ wzrostu, nie jest wysoki,

jest prawdziwa.

Zwolennicy tej koncepcji nie twierdzą jednak, że istnieje określona odpowiedź na pytanie, które $k$ spełnia ten warunek. W każdym doprecyzowaniu będzie to inne $k$. Dzięki temu można wyjaśnić pozorną tolerancyjność wyrażeń nieostrych: predykaty nieostre wydają się nam tolerancyjne, ponieważ nie ma jednej ostrej granicy między ich ekstensją i antyekstensją. W każdym dopusz- 
czalnym doprecyzowaniu ta granica przebiega w innym miejscu i stąd bierze się wrażenie tolerancyjności. Kosztem tego rozwiązania jest porzucenie logiki klasycznej na rzecz nieekstensjonalnej logiki z dziurami prawdziwościowymi ${ }^{8}$.

Istotnym problemem dla koncepcji nadwartościowania jest istnienie nieostrości wyższych rzędów. Nieostrość nie sprowadza się bowiem jedynie do braku wyraźnej granicy między wysokimi i tymi, którzy nie są wysocy. Tak, jak mamy kłopot z oddzieleniem wysokich studentów danego wydziału od pozostałych (ze względu na istnienie przypadków granicznych), tak mamy też problem ze wskazaniem tych studentów, którzy są przypadkami granicznymi predykatu „wysoki” (tym razem ze względu na istnienie przypadków granicznych przypadków granicznych). Podział danej grupy studentów na wysokich, przypadki graniczne i niewysokich nie jest wcale łatwiejszy niż podział tej grupy na wysokich i niewysokich. Tak, jak nie ma wyraźnej granicy między ekstensją i antyekstensją, tak też nie ma takiej granicy między ekstensją i przypadkami granicznymi. Powiedzieliśmy wcześniej, że dopuszczalne są te doprecyzowania, które granice przeprowadzają w obrębie zakresu nieostrości. Ponieważ granice samego zakresu nie są wyraźnie wytyczone, w konsekwencji nie da się jednoznacznie wskazać, które doprecyzowania są dopuszczalne, a co za tym idzie nie da się też powiedzieć, które zdania są prawdziwe, a które pozbawione wartości logicznej.

\subsection{Podwartościowanie}

Inne semantyczne rozwiązanie paradoksu nieostrości zostało zaproponowane przez Dominica Hyde'a (1997). Proponuje on koncepcję podwartościowania (subwaluacji), która jest koncepcją dualną wobec koncepcji nadwartościowania. Hyde również zakłada, że terminy nieostre dopuszczają wiele różnych sposobów

\footnotetext{
${ }^{8}$ Zastosowanie metody nadwartościowania sprawia, że funktory logiczne przestają być funktorami prawdziwościowymi. Zob. Fine (1975: 269). Załóżmy, że Marek jest przypadkiem granicznym dla predykatu 'łysy' i rozważmy zdanie 'Marek jest łysy lub nie jest łysy'. Każde doprecyzowanie jest ostre i posiada wyraźną granicę stosowalności danego predykatu. Zatem w każdym z doprecyzowań Marek znajdzie się albo po stronie łysych, albo po stronie niełysych. Powyższa alternatywa będzie więc prawdziwa w każdym dopuszczalnym doprecyzowaniu i, co za tym idzie, nadprawdziwa. Nie dotyczy to jednak żadnego z członów tej alternatywy; nie są one bowiem ani prawdziwe, ani fałszywe. Alternatywa może więc być prawdziwa, mimo że żaden z jej członów nie jest prawdziwy. Nie zawsze jednak tak się dzieje. Zdanie 'Marek jest łysy lub jest łysy' nie jest ani prawdziwe, ani fałszywe, ponieważ jest równoważne zdaniu 'Marek jest łysy' i ma różne wartości logiczne w różnych doprecyzowaniach. Zob. Odrowąż-Sypniewska (2000: 23).
} 
doprecyzowania, przy czym prawdę utożsamia nie z nadprawdą, lecz z prawdą w pewnym dopuszczalnym doprecyzowaniu. Zdanie „Jaś, który ma $175 \mathrm{~cm}$ wzrostu, jest wysoki”, jest prawdziwe, gdy istnieje przynajmniej jedno dopuszczalne doprecyzowanie, w którym to zdanie jest prawdziwe. Ponieważ istnieją zarówno takie dopuszczalne doprecyzowania, w których zdania o przypadkach granicznych są prawdziwe, jak i takie, w których zdania te są fałszywe, to wszystkie zdania o przypadkach granicznych są zarazem prawdziwe i fałszywe. Taka definicja prawdy wymaga logiki parakonsystentnej - tj. takiej, która jest sprzeczna (dla pewnych zdań $A$, zarówno $A$ jak i $\neg A$ należy do teorii), ale nie jest przepełniona (tj. nie jest tak, że dla każdego $A, A$ jest tezą tej teorii). Przepełnieniu zapobiega nieobowiązywanie prawa następstw sprzeczności: $A, \neg A \mid \neq B$. W logice zaproponowanej przez Hyde'a zasada niesprzeczności pozostaje zasadą logiczną:

$A, \neg A \mid \neq$ PdW $A \wedge \neg A$,

ponieważ $\mathrm{z}$ tego, że $A$ jest prawdziwe w jakimś doprecyzowaniu i $\neg A$ jest prawdziwe w jakimś doprecyzowaniu nie wynika, że jest takie doprecyzowanie, w którym prawdziwa jest koniunkcja ' $A \wedge \neg A$ '.

W książce Zagadnienie nieostrości wskazywałam, że rozwiązanie paradoksu nieostrości zaproponowane przez Hyde'a budzi wiele wątpliwości. Po pierwsze, nie jest jasne, jakie rozwiązanie Hyde proponuje. $\mathrm{Z}$ jednej strony bowiem autor artykułu pt. „From heaps and gaps to heaps of gluts” argumentuje, że modus ponens nie jest prawomocnym sposobem wnioskowania, $\mathrm{z}$ drugiej strony zaś twierdzi, że rozumowanie prowadzące do paradoksu jest obciążone błędem ekwiwokacji. Co więcej, traktuje to drugie twierdzenie jako wyjaśnienie pierwszego.

Hyde stara się dowieść, że wnioskowanie paradoksu nieostrości nie jest prawomocne. Jego argumentacja jest następująca:

Rozważmy zdanie ' $k$ ziarenek jest kopcem', gdzie $k$ ziarenek jest przypadkiem granicznym dla wyrażenia 'kopiec'. Zdanie to jest zarówno prawdziwe, jak i fałszywe. W szczególności jest więc prawdziwe. Ponieważ jednak jest również fałszywe, to implikacja materialna 'Jeżeli $k$ ziarenek jest kopcem, to również $k-1$ ziarenek jest kopcem' jest prawdziwa z powodu fałszywości poprzednika. Niemniej jednak $k-1$ ziarenek może zdecydowanie nie być kopcem, co spowoduje, że zdanie ' $k-1$ ziarenek jest kopcem' będzie fałszywe (Hyde 1997: 648).

Modus ponens prowadzi zatem od prawdziwych przesłanek do fałszywego wniosku. Jednakże obie przesłanki będą prawdziwe, tylko jeśli zdanie ' $k$ ziarenek jest kopcem' potraktujemy jako prawdziwe w pierwszej, a fałszywe 
w drugiej przesłance. Wyrażenia 'kopiec' trzeba zatem użyć w dwóch różnych znaczeniach. Przy jednym z tych znaczeń zdanie ' $k$ ziarenek tworzy kopiec' jest prawdziwe, a przy drugim - fałszywe. Tylko za sprawą takiej ekwiwokacji obie przesłanki mogą być jednocześnie prawdziwe. Jednakże zarzut, że modus ponens jest niepoprawnym wnioskowaniem, ponieważ wskutek popełnionej ekwiwokacji prowadzi od prawdziwych przesłanek do fałszywego wniosku, wydaje się zupełnym nieporozumieniem.

Po drugie, mówić o błędzie ekwiwokacji w rozumowaniu paradoksu nieostrości można tylko wówczas, gdy nieostrość traktuje się jako rodzaj wieloznaczności. Jednakże, moim zdaniem, nieostrość jest innym zjawiskiem językowym niż wieloznaczność i nie należy ich utożsamiać. Ponadto rozwiązanie Hyde'a stosuje się tylko do sformułowania (1) i nie pozwala na rozwiązanie paradoksu w sformułowaniu (2). Trzeba też podkreślić, że rozwiązanie odwołujące się do ekwiwokacji działa tylko, jeśli założymy, że nie ma nieostrości wyższych rzędów ${ }^{9}$.

\subsection{Nieostra trójwartościowość}

W swojej książce proponowałam koncepcję, inspirowaną uwagami Marka Sainsbury'ego i odwołującą się do logiki trójwartościowej Kleenego, w której nie są wyznaczone granice pomiędzy poszczególnymi wartościami logicznymi. Zdania, odnoszące się do przypadków granicznych, koncepcja ta traktuje jako zdania, które posiadają wartość logiczną nieokreśloności. Prawda, fałsz i nieokreśloność orzekane o zdaniach języka przedmiotowego są pojęciami nieostro nieostrymi, scil. jest zasadniczo nierozstrzygalne, czy mogłyby mieć przypadki graniczne. Rozwiązanie paradoksu nieostrości przyjęte w tej koncepcji polega na uznaniu, że przesłanka hipotetyczna nie jest prawdziwa. Rozwiązanie to nie usuwa nieostrości z języka, ponieważ nie twierdzi się, że wadliwa przesłanka jest fałszywa. Do wykazania, że wniosek jedynie pozornie wypływa z przesłanek, wystarcza nieokreśloność jednej z nich. Według koncepcji nieostrej trójwartościowości to, że jakiś predykat jest nieostry, polega nie tylko na tym, że mogą dla niego istnieć przypadki graniczne, ale także na tym, iż jest nierozstrzygalne, czy istnieją jakieś przedmioty, które nie są dla niego ani

\footnotetext{
${ }^{9}$ Hyde (1997: 648) zastrzega, że ,ignoruje komplikacje powstające w związku z nieostrością wyższych rzędów”. Wydaje się jednak, że musi on założyć, że zjawisko nieostrości wyższych rzędów nie istnieje, jeżeli chce dowieść nieważności modus ponens. Zob. J. Odrowąż-Sypniewska (2000, rozdz. 2).
} 
przypadkami pozytywnymi, ani przypadkami negatywnymi, ani przypadkami granicznymi. Taka charakterystyka nieostrości powoduje, iż pojęcie nieostrości wyższych rzędów okazuje się zbędne ${ }^{10}$.

\subsection{Epistemiczna koncepcja Timothy'ego Williamsona}

Żadnych zmian w logice klasycznej nie domaga się epistemiczna koncepcja nieostrości Timothy'ego Williamsona (1994). Twierdzi on bowiem, że przesłanka hipotetyczna jest fałszywa, a jej negacja - prawdziwa. Istnieje takie $k$, że człowiek, który ma $k$ włosów na głowie, jest łysy, ale człowiek, który ma $k+1$ włosów na głowie, nie jest łysy. Według Williamsona, istnieje wyraźna granica między łysymi i tymi, którzy łysi nie są, tyle że użytkownicy języka nie potrafią wskazać położenia tej granicy. Wyrażenia nieostre nie są zatem tolerancyjne. Jego zdaniem, takie rozwiązanie nie prowadzi do usunięcia nieostrości z języka, ponieważ nie wiemy (i nie możemy wiedzieć), które podstawienie przesłanki hipotetycznej jest prawdziwe.

Williamson uważa, że we wszystkich wypadkach, w których nasza wiedza jest niedokładna, obowiązuje pewien 'margines błędu'. Patrząc $\mathrm{z}$ pewnej odległości na drzewo, mogę ocenić jego wysokość tylko z pewnym przybliżeniem. Załóżmy, że powiem, że to drzewo ma $4 \mathrm{~m}$ wysokości i okaże się, że ono rzeczywiście ma dokładnie $4 \mathrm{~m}$ wysokości. Czy możemy powiedzieć, że wiedziałam, że to drzewo ma 4 m wysokości? Według Williamsona, nie mogłam tego wiedzieć, ponieważ obowiązująca $w$ takich wypadkach zasada marginesu błędu głosi, że ' $A$ ' jest prawdziwe we wszystkich wypadkach podobnych do wypadków, w których 'Wiem, że $A$ ' jest prawdziwe. Innymi słowy, możemy wiedzieć, że $A$, tylko jeżeli $A$ jest prawdziwe we wszystkich wystarczająco podobnych wypadkach. Jeżeli $A$ nie jest prawdziwe w wypadku, który jest wystarczająco podobny do wypadku, w którym $A$ jest prawdziwe, to w obu tych wypadkach wiedza dotycząca $A$ jest nieosiagalna. Wynika stąd, że możemy coś wiedzieć tylko z pewnym marginesem błędu. Nie mogę zatem wiedzieć (bez przeprowadzenia pomiarów), że drzewo ma dokładnie $4 \mathrm{~m}$ wysokości, ponieważ sytuacja, w której drzewo ma 3,9 m jest wystarczająco podobna do sytuacji, w której ma 4 m wysokości. Nie jest zatem tak, że 'To drzewo ma 4 m wysokości' jest prawdziwe we wszystkich wystarczająco podobnych wypadkach.

Podobnie rzecz się ma z określaniem położenia granic ekstensji predykatów nieostrych. Tyle tylko, że w tym wypadku chodzi nam nie tyle o wiedzę opartą na spostrzeżeniach zmysłowych, ale o wiedzę dotyczącą pojęć. Granice stoso-

\footnotetext{
${ }^{10}$ Zainteresowanych czytelników odsyłam do rozdziału czwartego mojej książki.
} 
wania predykatów nieostrych są wyznaczane przez ogólny sposób użycia, którego żaden użytkownik języka nie jest w stanie prześledzić. Znaczenie wyrażenia 'łysy' zależy od jego użycia, więc zmienia się tylko wtedy, gdy zmieniły się dyspozycje posługujących się danym językiem do używania tego wyrażenia. Dyspozycje poszczególnych użytkowników języka nie są jednak dokładnie takie same. Poszczególne użycie nie jest wrażliwe na małą zmianę w ogólnym sposobie użycia. Nasza zdolność odróżniania znaczeń jest zatem niedokładna. Załóżmy, że ktoś, kto teraz mówi 'Człowiek, który ma $k$ włosów na głowie, jest łysy', wygłasza zdanie prawdziwe, a użyty przez niego wyraz 'łysy' wyraża pojęcie łysy. Załóżmy też, że dla pojęcia tysy granica ekstensji przebiega między $k$ i $k+1$. Wygłaszający zdanie 'Człowiek, który ma $k$ włosów na głowie, jest łysy', mógłby jednak wygłosić je w sytuacji, w której ogólny sposób użycia byłby inny i wyraz 'łysy' wyrażałby pojęcie tysy*, a nie pojęcie łysy. Pojęcie tysy* jest zaś takie, że maksymalna liczba włosów, jakie łysy* człowiek może mieć na głowie, to $k-1$ (to jest dla niego granica ekstensji przebiega między $k-1 \mathrm{i} k$ ). W takiej sytuacji zdanie 'Człowiek, który ma $k$ włosów na głowie, jest łysy’ byłoby fałszywe. Zatem nawet jeżeli twierdzenie 'Człowiek, który ma $k$ włosów na głowie, jest łysy' jest prawdziwe, to ktoś, kto je wygłasza, nie może wiedzieć, że to, co mówi jest prawdą, bo nie wie, które pojęcie (tysy czy tysy*) jest znaczeniem użytego przez niego wyrazu 'łysy' (por. Odrowąż-Sypniewska 2000: 71).

Z konieczności jesteśmy więc ignorantami w kwestii położenia granic wyrażeń nieostrych. Zasadniczą trudnością dla tej koncepcji jest podanie przekonującego uzasadnienia, że granice ekstensji wyrażeń nieostrych rzeczywiście istnieją. Koncepcja ta bowiem zakłada, że ów niepoznawalny dla nas ogólny sposób użycia wyznacza precyzyjne granice pomiędzy łysymi i niełysymi, kopcami i niekopcami itd. Nie trzeba dodawać, że takie założenie jest bardzo kontrowersyjne.

\section{Kontekstualistyczna koncepcja nieostrości}

Jak już wspominałam, nieostrości nie da się sprowadzić do zależności kontekstowej. Ostatnio zaproponowano jednak koncepcje, które rozwiązują paradoks nieostrości, odwołując się istotnie do zależności kontekstowej wyrażeń nieostrych. Kontekstualiści sądzą, że wyrażenia nieostre - tak jak wyrażenia okazjonalne - mają różne odniesienie w różnych kontekstach użycia. Tak jak różne egzemplarze wyrażenia 'ty' mogą wskazywać różne osoby, tak różne wypowiedzenia wyrażeń 'wysoki' czy 'łysy' mogą odnosić się do różnych 
własności. Z tego powodu zasadę tolerancji należy odrzucić: wyrażenie 'łysy', które pojawia się w poprzedniku tej przesłanki, może oznaczać inną własność niż 'łysy', pojawiające się w następniku. Odrzucenie tej przesłanki nie prowadzi jednak do przyjęcia jej klasycznej negacji: ' $\exists k(F(k) \wedge \neg F(k+1)$ )', gdzie ' $F$ ' oznacza np. bycie łysym. Skoro ' $F$ ' w pierwszym i drugim członie negacji może oznaczać różne własności, to nie ma żadnego powodu, aby twierdzić, że takie $k$ będzie istniało.

\subsection{Kontekstualizm Stewarta Shapiro}

Jedną z zaproponowanych kontekstualistycznych teorii nieostrości jest koncepcja Stewarta Shapiro (2003). Według niego, wyrażenia nieostre są podwójnie zależne od kontekstu. Po pierwsze są zależne od kontekstu zewnętrznego (np. to, kogo uznajemy za łysego zależy od tego, czy rozmowa odbywa się na spotkaniu firmy produkującej szampony, czy firmy robiącej peruki), a po drugie zależą również od wewnętrznego kontekstu konwersacyjnego. W jednej rozmowie Jan może zostać uznany za łysego, ale w innej może być potraktowany jako niełysy (mimo że uczestnicy konwersacji i pozostałe elementy kontekstu zewnętrznego nie zmieniły się).

Shapiro skupia się na innym jeszcze sformułowaniu paradoksu nieostrości tzw. wymuszonym marszu. W tym sformułowaniu paradoks wygląda następująco. Ustawiamy mężczyzn w szereg, zaczynając od zupełnie łysego, tak aby sąsiadujący ze sobą mężczyźni różnili się tylko jednym włosem ${ }^{11}$. Ostatni mężczyzna ma 150000 włosów na głowie, więc łysy nie jest. Następnie prosimy grupę kompetentnych użytkowników języka, aby szli wzdłuż tego szeregu i odpowiadali na pytanie 'Czy ten człowiek jest łysy?'. Na początku nasi sędziowie nie będą mieli kłopotu z odpowiedzią i powiedzą 'tak'. Paradoks polega na tym, że nasze oczekiwania względem nich są sprzeczne: $\mathrm{z}$ jednej strony oczekujemy, że różnica jednego włosa nie będzie dla nich ważna i nie spowoduje zmiany osądu, z drugiej jednak oczekujemy, że o mężczyznach stojących na końcu powiedzą, że nie są łysi.

W rozwiązaniu Shapiro istotną rolę odgrywają przede wszystkim trzy tezy. Po pierwsze, proponuje on, żeby zamiast tradycyjnej zasady tolerancji przyjać jej słabszą wersję:

\footnotetext{
${ }^{11}$ Zamiast ustawiać mężczyzn w taki szereg (co z oczywistych względów byłoby bardzo trudne, jeśli nie niewykonalne), możemy komputerowo wygenerować serię zdjęć jednego mężczyzny, który na pierwszym zdjęciu jest całkiem łysy, a na kolejnych ma o jeden włos więcej.
} 
Załóżmy, że predykat $P$ jest tolerancyjny, a dwa przedmioty $a$ i $a$ ' różnią się tylko minimalnie pod względem $P$. Jeśli kompetentny użytkownik języka twierdzi, że $a$ jest $P$, to nie może twierdzić, że $a^{\prime}$ nie jest $P$ (Shapiro 2003: 42).

Różnica polega na tym, że słabsza wersja nie mówi o tym, kiedy $a$ ' jest $P$; mówi tylko, kiedy użytkownik języka nie może twierdzić, że $a$ ' nie jest $P$. Nie wyklucza się tutaj np., że użytkownik może zmienić zdanie albo w ogóle $a$ 'się nie zajmować.

Drugim istotnym elementem koncepcji Shapiro jest odwołanie do idei zapisu konwersacyjnego (conversational score) Davida Lewisa (1983). Taki zapis konwersacyjny jest 'lokalną wersją wspólnej wiedzy' i zawiera m.in. presupozycje, zakresy kwantyfikatorów, odniesienia nazw własnych, odpowiednie klasy porównawcze, wzorce dla 'wysoki', 'łysy' itd. Cechą charakterystyczną takiego zapisu jest to, że działają w nim reguły dostosowawcze (rules of accommodation). W efekcie działania takich reguł ,cokolwiek zostanie powiedziane, będzie tak interpretowane, aby można to było traktować jako poprawne" (Lewis 1983: 240).

Trzecią ważną tezą, postulowaną przez Shapiro (2003: 43), jest twierdzenie o niezdeterminowaniu przypadków granicznych (the open-texture thesis), które brzmi następująco:

Jeśli $a$ jest przypadkiem granicznym $P$, to użytkownik języka może powiedzieć, że $P a$ i może powiedzieć, że nie $P a$, i nie naruszy w ten sposób żadnych reguł językowych.

Zatem Shapiro zakłada, że przypadki graniczne możemy traktować tak, jak chcemy.

Zobaczmy teraz, w jaki sposób te trzy składniki koncepcji (osłabiona zasada tolerancji, idea zapisu konwersacyjnego i reguł dostosowawczych oraz teza o niezdeterminowaniu przypadków granicznych) pomagają w rozwiązaniu paradoksu nieostrości.

Sędziowie przechodzą od jednego mężczyzny do drugiego i deklarują, że jest on łysy. Załóżmy, że dochodzą do 974 człowieka w szeregu. Po długiej dyskusji i przekonywaniu, w głosowaniu zwycięża werdykt, że mężczyzna 974 jest łysy. Zatem zdanie 'Mężczyzna 974 jest łysy' zostaje dołączone do zapisu konwersacyjnego. Sędziowie przechodzą do mężczyzny 975. Tym razem znowu po długotrwałej dyskusji - zwycięża przekonanie, że mężczyzna 975 nie jest łysy. Zdanie 'Człowiek 975 jest łysy' zostaje dołączone do zapisu konwersacyjnego. Zmiana werdyktu nie pociąga za sobą złamania osłabionej zasady tolerancji. Albowiem zgodnie z tą zasadą, deklarując, że człowiek 975 nie jest 
łysy, ochotnicy tym samym zaprzeczają, że człowiek 974 jest łysy. Od razu uruchomione zostają reguły dostosowawcze i zdanie 'Człowiek 974 jest łysy' zostaje usunięte z zapisu konwersacyjnego. Razem z 'Człowiek 974 jest łysy' z zapisu znika 'Człowiek 973 jest łysy' i kilka innych ostatnich osądów. Zmiana oceny nie narusza zasady tolerancji, ponieważ towarzyszy jej wycofanie innych osądów z zapisu konwersacyjnego. Możemy założyć, że sędziowie zdecydują się na wycofanie co najmniej kilku ostatnich sądów, ale w pewnym momencie uznają, że owo wycofywanie należy zakończyć. Zgodzą się np., że mężczyzna 953 jest łysy i zdanie 'Mężczyzna 953 jest łysy' nie może być usunięte z zapisu konwersacyjnego. Decydując się na uznanie zdania 'Mężczyzna 953 jest łysy', zgadzają się tym samym, że umieszczone przed chwilą w zapisie zdanie 'Mężczyzna 954 nie jest łysy' powinno jednak z tego zapisu być usunięte. To samo dotyczy kolejnych zdań, aż do momentu, w którym uczestnicy uznają, że dany człowiek rzeczywiście łysy nie jest i nie zgodzą się na usunięcie odpowiedniego zdania z zapisu. To z kolei spowoduje usunięcie innych niedawno umieszczonych $\mathrm{w}$ zapisie zdań. Ta procedura ma się powtarzać (przynajmniej dopóty, dopóki uczestnicy nie odmówią współpracy).

Rozwiązanie paradoksu w wersji 'wymuszonego marszu' jest zatem następujące: mężczyźni na początku szeregu są łysi, mężczyźni na końcu szeregu nie są łysi, ale nie da się wskazać wyraźnej granicy miedzy łysymi a niełysymi, ponieważ ta granica ciagle się przesuwa. Przy czym nigdy nie będzie tak, żebyśmy mogli uznać, że każdemu mężczyźnie z szeregu zostało przypisane bycie łysym bądź bycie niełysym. Ale taka już natura nieostrości... (por. Shapiro 2003: 54).

Jeśli chodzi o rozwiązanie paradoksu w wersji tradycyjnej z przesłanką hipotetyczną, to polega ono na uznaniu, że ta przesłanka jest fałszywa, ale nie ma kontrprzykładu, ponieważ nie ma takiej liczby $k$, że 'człowiek $k$ jest łysy' i 'człowiek $k+1$ nie jest łysy' są jednocześnie w zapisie konwersacyjnym. Przypomina to rozwiązanie znane z koncepcji nadwartościowania i rzeczywiście Shapiro uważa, że najlepszą logiką wyrażeń nieostrych jest właśnie nadwartościowanie ${ }^{12}$.

${ }^{12}$ Przy czym zauważa od razu, że nie jest to logika idealna i do tego, aby uchwycić wszelkie niuanse związane z nieostrością potrzebna jest - być może - logika parakonsystentna. Shapiro (2003: 49) przyznaje, że jego przykład jest sztuczny, a w pełni adekwatna koncepcja nieostrości powinna uwzględniać przypadki, w których w zapisie konwersacyjnym znajdują się zdania sprzeczne. Nadwartościowanie nie jest całkowicie adekwatne dla jego analizy nieostrości, ponieważ koncepcja nadwartościowania jako prawdziwe traktuje tylko zdania prawdziwe we wszystkich doprecyzowaniach. Shapiro tymczasem - za Lewisem - chciałby jako (wystarczająco) prawdziwe traktować te zdania, które są prawdziwe w wielu doprecyzowaniach. Por. Lewis (1983: 244). Shapiro (2003: 43) pisze, że ,prawda jest czymś więcej niż nadprawdą, a prawomocność jest czymś więcej niż koniecznym zachowaniem nadprawdy”. 


\subsection{Krytyka koncepcji Shapiro}

Najpoważniejszy zarzut, na jaki narażona jest koncepcja Shapiro, to bagatelizowanie nieostrości wyższych rzędów. Jak już wspominałam, nieostrość wyższych rzędów jest zjawiskiem, polegającym na braku granic między przypadkami pozytywnymi i przypadkami granicznymi oraz przypadkami granicznymi i przypadkami negatywnymi. Brak tych granic powoduje, że nie wiemy, kiedy jeszcze mamy do czynienia ze zdecydowanie łysymi, a kiedy już z przypadkami granicznymi tego predykatu. Jeśli zaś tego nie wiemy, to nie wiemy również, w stosunku do których przypadków obowiązuje teza o niezdeterminowaniu. Jak pamiętamy, teza ta głosi, że jeśli mamy do czynienia z przypadkiem granicznym, to od nas zależy, jak go potraktujemy. Ale jeśli nie wiemy, które przypadki są graniczne, to nie wiemy, kiedy z tej tezy możemy skorzystać. Jeśli zatem spotykam kogoś, o kim sądzę, że jest przypadkiem granicznym bycia łysym, to nie wiem, czy mogę po prostu sama podjąć decyzję, czy nazwać go 'łysym', czy też powinnam podporządkować się regułom językowym.

Inny problem jest związany z zachowaniem kompetentnych użytkowników, osądzających przypadki graniczne ${ }^{13}$. Shapiro zakłada, że ci użytkownicy jakoś dojdą do porozumienia (np. w drodze głosowania). Wydaje się jednak, że dwóch kompetentnych użytkowników może osądzać przypadek graniczny inaczej i - co więcej - upierać się przy swoim ${ }^{14}$. Co wtedy dzieje się z zapisem konwersacyjnym? Lewis zauważa, że w różnych rozmowach obowiązują różne standardy: wyższe i niższe. Załóżmy, że $A$ mówi: 'Francja jest sześciokątna'. Jeśli $B$ przed chwilą powiedział, że Włochy mają kształt buta i nikt nie zaprzeczył, to możemy oczekiwać, że nikt nie zaprotestuje przeciwko wypowiedzi $A$ (por. Lewis 1983: 245). Może jednak być tak, że na wypowiedź $A$ zareaguje $C$, mówiąc: 'Francja nie jest sześciokątna'. Co wtedy powinien zrobić $A$ ? Wydaje się, że mógłby powiedzieć tak: 'OK. Zależy, jak bardzo precyzyjny chcesz być. Jeśli chcesz być bardzo precyzyjny, to zgoda: Francja nie jest sześciokątna'. W rozmowie $B$ i $A$ obowiązywały niskie standardy dla bycia sześciokątnym, wypowiedź $C$ je podwyższyła. To, co można było uznać za prawdę przy niższych standardach, przestało być prawdziwe przy wyższych. Jednakże można uważać, że sytuacja z wyrażeniami nieostrymi jest inna. Załóżmy, że $A$ mówi: 'Jaś jest wysoki (jak

\footnotetext{
${ }^{13}$ Podobny zarzut stawia Rosanna Keefe (2003:78).

${ }^{14}$ Warto zauważyć, że zezwala na to postulowana przez Shapiro teza o niezdeterminowaniu przypadków granicznych. Notabene Shapiro sądzi, że granice ekstensji predykatów nieostrych będą różnie ustalane w różnych rozmowach i zapisach konwersacyjnych (stąd nadwartościowanie). Wydaje się jednak, że te granice mogą być różnie wyznaczane nawet przez uczestników tej samej rozmowy.
} 
na siedmioletniego chłopca)', a $B$ zaprzecza: 'Jaś nie jest wysoki (jak na siedmioletniego chłopca)'. Jeśli Jaś jest przypadkiem granicznym bycia wysokim siedmioletnim chłopcem, to $A$ - inaczej niż w wypadku sześciokątności może nadal obstawać przy swoim i upierać się, że Jaś jest wysoki. Także $B$ może nie chcieć ulec i twierdzić, że Jaś wysoki nie jest. W sytuacji, w której wypowiedź $A$ 'Jaś jest wysoki' spotyka się z odpowiedzią $B$ 'Jaś nie jest wysoki', standardy bycia wysokim nie zostają automatycznie podniesione. Dopiero wtedy, gdy $A$ zgodzi się z $B$ i przyzna, że Jaś jednak wysoki nie jest, można uznać, że w tej rozmowie zaczynają obowiązywać wyższe standardy i usunąć zdanie 'Jaś jest wysoki' z zapisu konwersacyjnego. Jeśli jednak $A$ i $B$ wygłaszają sprzeczne sądy i żaden $z$ nich nie chce ustąpić, to żadne zdanie nie może zostać usunięte. Istotna różnica między wyrażeniami takimi, jak 'sześciokątny' i 'płaski' z jednej strony, a 'wysoki' i 'bogaty' z drugiej polega na tym, że tylko te pierwsze mają dwa sensy: ścisły i luźny. Możemy mówić o doskonałym sześciokącie albo o powierzchni absolutnie płaskiej, ale nie możemy mówić o człowieku absolutnie bogatym czy w najwyższym stopniu wysokim ${ }^{15}$. Możemy domniemywać, że ktoś, kto reaguje zaprzeczeniem na wygłoszone przez interlokutora zdanie, że Francja jest sześciokątna, chce posługiwać się terminem 'sześciokątny' w sensie bardziej zbliżonym do sensu absolutnego. Takiego domniemania nie ma w wypadku większości terminów nieostrych. Ponieważ nie ma ścisłego i nieścisłego sensu bycia wysokim, to nie możemy zakładać, że $B$ chodzi o zastosowanie w rozmowie wyższych standardów bycia wysokim. Wygłoszenie przez $B$ zdania 'Jaś nie jest wysoki' nie powinno zatem uruchamiać reguł dostosowawczych, których zadaniem byłoby usunięcie z zapisu zdania 'Jaś jest wysoki'. Można by wręcz twierdzić, że to, iż dwa sprzeczne twierdzenia, dotyczące jakiegoś przypadku granicznego, mogą w tym samym czasie być w zapisie konwersacyjnym (pod warunkiem, że nie są wypowiedziane przez tę samą osobę), jest wyróżniającą cechą wyrażeń nieostrych.

Co dzieje się z zapisem konwersacyjnym, gdy $A$ i $B$ uświadomią sobie, że ich sprzeczne sądy dotyczą przypadku granicznego bycia wysokim siedmiolatkiem? Są tu dwie możliwości. Gdy $A$ i $B$ zdadzą sobie sprawę, że mają do czynienia z przypadkiem granicznym, mogą albo nadal obstawać przy swoim, albo zrezygnować z dotychczas wygłaszanych osądów i uznać, że spór jest bezprzedmiotowy. Żadna $\mathrm{z}$ tych dwóch możliwości nie pasuje jednak do rozwiązania, zaproponowanego przez Shapiro. Druga z nich prowadzi do wycofania dotychczasowych sądów i powstrzymania się od wydawania dalszych. Tak sprawę widzi Crispin Wright, według którego jedną z istotnych cech

15 'Łysy’ jest pod tym względem podobne do 'płaski’, ponieważ ma dwa sensy: absolutny (ktoś, kto jest całkowicie pozbawiony włosów) i luźny (ktoś, kto ma włosów bardzo mało). 
nieostrości jest 'dozwolona niezgoda', przy czym - według Wrighta - dozwolone jest powstanie takiej niezgody, a nie jej kontynuowanie. Wright (1994: 138) twierdzi, że możliwa jest sytuacja, w której dwaj rozmówcy, bez swojej winy, mają sprzeczne opinie, dotyczące pewnego przypadku. Jednakże, gdy zorientują się, że przedmiotem ich sporu jest przypadek graniczny, powinni przestać się spierać wiedząc, że ich dyskusja jest bezprzedmiotowa. Jeśli uznajemy, że w stosunku do przypadku granicznego najwłaściwsze postępowanie polega na zawieszeniu sądu, to logika z dziurami prawdziwościowymi - taka, jak nadwartościowanie - wydaje się najbardziej odpowiednia do analizy zdań o przypadkach granicznych. Można jednak uważać, że $A$ i $B$ - nawet gdy zdadzą sobie sprawę $\mathrm{z}$ tego, że Jaś jest przypadkiem granicznym - nadal będą trwać przy swoich opiniach. Jeśli uznajemy takie postępowanie za dopuszczalne, to wydaje się, że najwłaściwszą logiką nieostrości będzie logika parakonsystentna ${ }^{16}$. Jak widzieliśmy powyżej, logikę parakonsystentną, jako właściwą do modelowania nieostrości, proponuje koncepcja podwartościowania Hyde'a. Zaadaptowanie podwartościowania do potrzeb koncepcji Shapiro jest jednak problematyczne. Kontekstualizm Shapiro jest, moim zdaniem, kontekstualizmem nieokazjonalistycznym, to jest takim, w którym utrzymuje się, że tym, co zmienia się wraz z kontekstem jest ekstensja wyrażeń nieostrych, a nie ich znaczenie. Twórca kontekstualizmu nieokazjonalistycznego John MacFarlane zauważa - za Davidem Kaplanem - że kontekst pełni dwie różne funkcje: funkcję determinowania treści (tj. pomaga $\mathrm{w}$ ustaleniu, jaki sąd został wyrażony) oraz funkcję determinowania okoliczności ewaluacji (tj. wskazuje, w jakich okolicznościach ewaluacji sąd powinien być oceniany). To, jak kontekst te dwie role wypełnia, można zobaczyć na przykładzie debaty między temporalizmem a eternalizmem (zob. MacFarlane 2007: 233 i n.). Weźmy zdanie $S$ : „Sokrates siedzi”. Temporaliści uważają, że $S$ zawsze wyraża ten sam sąd (mianowicie sąd, że Sokrates siedzi), który ma różne wartości logiczne o różnych czasach (jest prawdziwy wtedy, gdy Sokrates siedzi, a fałszywy wtedy, gdy Sokrates np. leży). Eternaliści z kolei sądzą, że $S$ wyraża różne sądy o różnych czasach. O czasie $\mathrm{t}_{1} S$ wyraża sąd, że Sokrates siedzi o $\mathrm{t}_{1}$, o czasie $\mathrm{t}_{2} S$ wyraża sąd, że Sokrates siedzi $\mathrm{o}_{2}$ itd. Każdy z tych sądów ma stałą wartość logiczną. Zatem według eternalistów, zdanie $S$ jest okazjonalne: wyraża różne sądy w zależności od kontekstu. Temporaliści zakładają, że kontekst odgrywa rolę ustalania okoliczności ewaluacji, a eternaliści sądzą, że kontekst ustala treść wyrażanego sądu. Eternalistów można porównać do kontekstualistów standardowych, a temporalistów - do kontekstualistów nieokazjonalistycznych. Dla eternalistów okolicznościami ewaluacji są światy możliwe, dla temporalistów zaś pary uporządkowane,

\footnotetext{
${ }^{16}$ Jak już wspominałam, sam Shapiro tak sugeruje. Por. wyżej, przyp. 14.
} 
złożone ze światów możliwych i czasów. Podobnie dla kontekstualistów standardowych okolicznościami ewaluacji są światy możliwe, a dla kontekstualistów nieokazjonalistycznych pary uporządkowane, złożone ze światów i parametru 'uznawany-za' (the counts-as parameter). Weźmy zdanie Z: 'Kasia jest wysoka'. Według kontekstualistów standardowych, 'jest wysoka' jest wyrażeniem okazjonalnym, mającym różną treść w różnych kontekstach. Na przykład w kontekście $\mathrm{k}_{1} Z$ znaczy, że Kasia jest wysoka jak na siedmiolatkę (i jest prawdziwe), a w kontekście $\mathrm{k}_{2}$ znaczy, że Kasia jest wysoka jak na zawodniczkę koszykówki (i jest fałszywe). Według MacFarlane'a, 'jest wysoka' ma taką samą treść we wszystkich kontekstach, a okolicznościami ewaluacji są pary złożone ze świata i parametru 'uznawana-za', który to parametr jest funkcją $\mathrm{z}$ własności do intensji (które z kolei są funkcjami ze światów do ekstensji) ${ }^{17}$ :

Parametr 'uznawany-za' jest tak nazywany dlatego, że ustala jakie rzeczy muszą być, aby być uznawane za posiadające własność bycia wysokim (albo dowolną inną własność) w okolicznościach ewaluacji (MacFarlane 2007: 246).

Parametr ten zależy od rozmaitych cech kontekstu, m.in. od tematu rozmowy i intencji rozmówców ${ }^{18}$. W kontekście $\mathrm{k}_{1}$, w którym mowa jest o siedmiolatkach, funkcja 'uznawana-za' może przypisać własności bycia wysoką tę samą intensję, którą przypisuje własności bycia wysoką-jak-na-siedmiolatkę. W kontekście $\mathrm{k}_{2}$, w którym mowa o koszykarkach, funkcja 'uznawana-za' może przypisać własności bycia wysoką tę samą intensję, co własności bycia wysokim-jak-na-koszykarkę.

Wydaje mi się, że kontekstualistyczna koncepcja Shapiro jest bliższa kontekstualizmowi nieokazjonalistycznemu niż standardowemu (por. Åkerman, Greenough 2009). Shapiro mówi bowiem wyraźnie, że tym, co się zmienia wraz z kontekstem, jest ekstensja predykatów nieostrych (por. Shapiro 2003: 57, 60, 67). Jeśli mam rację, to podwartościowanie nie może zostać przyjęte jako logika tej koncepcji. Jak już wspominałam, koncepcja podwartościowania zakłada, że terminy nieostre podobne są do wyrażeń wieloznacznych i mają wiele różnych choć bardzo do siebie zbliżonych - znaczeń. Tylko takie założenie umożliwia Hyde'owi argumentowanie, że rozumowanie, prowadzące do paradoksu nieostrości, obciążone jest błędem ekwiwokacji. Jeśli natomiast przyjmujemy, że terminy nieostre mają jedno znaczenie (treść), które nie zmienia się wraz

\footnotetext{
${ }^{17}$ Kontekstualizm nieokazjonalistyczny odchodzi zatem od przyjmowanego zazwyczaj założenia, że znaczenie determinuje ekstensję.

${ }^{18}$ Wydaje się, że tym, co wyznacza parametr 'uznawany-za', w koncepcji Shapiro mógłby być zapis konwersacyjny.
} 
z kontekstem, to zastosowanie podwartościowania do analizy nieostrości traci uzasadnienie. Jednakże można by próbować argumentować, że predykaty nieostre mają jedną niezmienną treść, ale różne ekstensje w zależności od kontekstu. Trzeba by wtedy przyjąć, że doprecyzowania nie są doprecyzowaniami znaczenia, lecz wyłącznie doprecyzowaniami ekstensji. Predykat ma jedno stałe znaczenie, które tylko 'z grubsza' determinuje ekstensję. W różnych kontekstach potrzebne będą różne doprecyzowania tejże ekstensji. Trzeba jednak pamiętać, że takie rozwiązanie jest do przyjęcia, tylko jeśli odrzuca się - tak, jak to robią kontekstualiści nieokazjonalistyczni - założenie o determinowaniu ekstensji przez intensję ${ }^{19}$. Przy takiej interpretacji wyrażenie o jednej ustalonej intensji ma różne ekstensje $\mathrm{w}$ zależności od kontekstu. Umożliwia to parametr 'uznawany-za', który tę samą intensję może przeprowadzić w różne ekstensje (w zależności od tematu rozmowy i intencji nadawcy). Jednakże, przy takim rozumieniu doprecyzowań (jako precyzacji wyłącznie ekstensji, a nie znaczenia), rozwiązanie podane przez Hyde'a nie da się zastosować. Nie możemy bowiem mówić o ekwiwokacji w sytuacji, w której wyrażenie nieostre ma stałe znaczenie w całym rozumowaniu prowadzącym do paradoksu.

\section{Zakończenie}

Filozofowie języka widzą oczywiście pożytki z posiadania wyrażeń nieostrych w języku (zwłaszcza języku naturalnym). Niepokoi ich jednak fakt, że przy użyciu tych wyrażeń można konstruować paradoksy. To prawda, że w codziennym użyciu terminów nieostrych groźba skonstruowania paradoksu jest bardzo mało realna, ale świadomość tego, że takie paradoksy dla każdego terminu nieostrego da się sformułować, jest wystarczająco niepokojąca ${ }^{20}$. Paradoksy pokazują, że wyrażenia nieostre nie są tolerancyjne tak, jak nam się pozornie wydaje. Taka prosta, czy wręcz naiwna, definicja tolerancyjności nieubłaganie prowadzi do sprzeczności. Pozór tolerancyjności trzeba zatem wytłumaczyć inaczej, przy czym taka analiza nie może prowadzić do uznania istnienia

${ }^{19}$ Zarówno w nadwartościowaniu, jak i w podwartościowaniu doprecyzowania miały przede wszystkim być doprecyzowaniami ekstensji. Fine zakłada np., że znaczenie wyrażenia nieostrego jest wypadkową znaczenia aktualnego i potencjalnego, gdzie znaczenie aktualne jest tym, co determinuje ekstensję i antyekstensję, a znaczenie potencjalne składa się z różnych możliwości doprecyzowania. Doprecyzowanie nie zmienia zatem znaczenia wyrażenia, ponieważ możliwość takiego doprecyzowania jest już w owo znaczenie wpisana. Por. Fine (1974: 277).

${ }^{20}$ Co do tej kwestii por. moją polemikę z Mieszkiem Tałasiewiczem (Odrowąż-Sypniewska, Tałasiewicz 2005). 
precyzyjnie wytyczonych i widocznych dla wszystkich użytkowników granic. Poza rozwiązaniem paradoksu nieostrości, adekwatna koncepcja nieostrości musi również powiedzieć, w jaki sposób należy traktować przypadki graniczne, a w szczególności, jak postępować w wypadku konfliktu, kiedy dwóch rozmówców ma sprzeczne zdanie na temat danego przypadku granicznego. Taka koncepcja powinna określić, czy rację mogą mieć obaj, żaden, czy jeden z nich i jeśli tak, to który.

Naszkicowałam kilka najbardziej znaczących koncepcji nieostrości: nadwartościowanie, podwartościowanie, koncepcję stopni prawdy i epistemiczną koncepcję Williamsona. Wspomniałam również o zaproponowanej przeze mnie koncepcji trzech nieostrych wartości logicznych. Bardziej szczegółowo przedstawiłam nową kontekstualistyczną koncepcję Stewarta Shapiro, dla której znacznie większe znaczenie mają pytania epistemologiczne i psychologiczne Fary niż pytanie semantyczne. Można by wręcz powiedzieć, że ta koncepcja ma być filozoficznym uzasadnieniem przyjęcia nadwartościowania jako właściwej analizy nieostrości. Próbowałam pokazać, że koncepcja Shapiro nie spełnia pokładanych w niej nadziei, przede wszystkim dlatego, że nie bierze pod uwage nieostrości wyższych rzędów. Istnienie przypadków granicznych stanowi istotną przeszkodę $\mathrm{w}$ zastosowaniu tezy o niezdeterminowaniu przypadków granicznych i stawia pod znakiem zapytania adekwatność zaproponowanego rozwiązania paradoksu wymuszonego marszu. Ponadto koncepcja nie rozstrzyga, jak należy postępować $\mathrm{w}$ zdarzających się przecież w życiu codziennym - i to w trakcie jednej rozmowy - konfliktach dotyczących przypadków granicznych.

Mimo tych zastrzeżeń, wydaje mi się, że analiza dokonywana z perspektywy kontekstualizmu nieokazjonalistycznego jest najbardziej obiecującą drogą poszukiwań rozwiązania paradoksu nieostrości.

\section{Bibliografia}

Åkerman, J., Greenough, P. 2009. „Vagueness and non-indexical contextualism”, [w:] S. Sawyer (red.), 8-23.

Beall, J. C. (red.), 2003. Liars and Heaps. New Essays on Paradox, Oxford: Clarendon Press.

Fine, K. 1975. „Vagueness, truth and logic”, Synthese 30, 265-300.

Fara, D. 2000. „Shifting sands: An interest-relative theory of vagueness”, Philosophical Topics 28, 45-81.

Horgan, T. (red.), 1994. „Vagueness”, The Southern Journal of Philosophy 33. Hyde, D. 1997. „From heaps and gaps to heaps of gluts”, Mind 106, 641-660. 
Keefe, R. 2003. „Context, vagueness, and the sorites”, [w:] J. C. Beall (red.), 73-83.

Lewis, D. 1983. „Scorekeeping in a language game”, [w:] D. Lewis, 233-249.

Lewis, D. 1983. Philosophical Papers 1, Oxford: Oxford University Press.

MacFarlane, J., 2007. „Semantic minimalism and nonindexical contextualism”, [w:] G. Preyer, G. Peter (red.), 240-250.

MacFarlane, J. 2009. „Nonindexical contextualism”, Synthese 166, 231-250.

Odrowąż-Sypniewska, J. 2000. Zagadnienie nieostrości, Warszawa: WFiS UW.

Odrowąż-Sypniewska, J. 2005. „O nieostrości i niewyraźności”, Ruch Filozoficzny 2, 229-235.

Odrowąż-Sypniewska, J. 2010. „Vagueness and contextualism”, [w:] P. Stalmaszczyk (red.), 169-183.

Odrowąż-Sypniewska, J., Tałasiewicz, M. 2005. „Rzeczywista możliwość czy możliwe urzeczywistnienie? Dialog o pragmatycznej koncepcji nieostrości”, Filozofia Nauki $3(51), 95-114$.

Preyer, G., Peter G. (red.), 2007. Context-Sensitivity and Semantic Minimalism, Oxford University Press.

Sawyer, S. (red.), 2009. New Waves in the Philosophy of Language, London: Palgrave Macmillan.

Shapiro, S. 2003. „Vagueness and conversation”, [w:] J. C. Beall (red.), 39-72.

Stalmaszczyk P. (red.), 2010. Philosophy of Language and Linguistics 1, Frankfurt am Main: Ontos-Verlag.

Unger, P. 1979. „There are no ordinary things”, Synthese 41, 117-154.

Williamson, T. 1994. Vagueness, London-New York: Routledge.

Wright, C. 1994. „The epistemic conception of vagueness”, [w:] T. Horgan (red.), 133-160. 